\title{
Tissue Edema and Arterial Lesions Produced by Pure Submaxillary Gland Renin of Mouse
}

\author{
Kaoru Onoyama, M.D., Teruo Omae, M.D., \\ and Tadashi InAgami, * M.D.
}

\begin{abstract}
Summary
In order to identify the nature of the substance(s) that causes pancreatic edema, pleural effusion, hematocrit increase, and vascular lesion upon administration of renal extracts, effects of a pure preparation of submaxillary gland renin of mouse on blood vessels were studied. This enzyme was administered intraperitoneally to conscious anehpric rats. Blood pressure elevation recorded under unrestricted conditions was proportional to pancreatic edema, pleural effusion, hematolcrit increase, and vascular lesions in small arteries and arterioles. Since the renin administered does not contain any substances and since the function of this enzyme is quite analogous to renal renin, these results have been interpreted to indicate that renin possesses both pressor and permeability activities and that the action of renin alone can account for the vascular lesions and the increased vascular permeability.
\end{abstract}

\section{Additional lndexing Words :}

Pressor activity Permeability activity Pancreatic edema Pleural effection Hematocrit Fibrinoid necrosis

Q INCE the original observation by Winternitz et $\mathbf{a l}^{\mathbf{1}}{ }^{\mathbf{1}}$ in 1940 , it has been $D$ well documented that administration of renal extract to bilaterally nephrectomized rats produces a syndrome of arterial and arteriolar necrosis, tissue edema, and serous effusion which resemble those found in malignant hypertension.

The factor(s) of renal origin responsible for these lesions, however, has not been clearly identified. Many investigators have considered renin as the most pertinent factor ${ }^{2-7)}$ whereas others have proposed a substance(s) other than renin to play, at least, a partial role in the genesis of the above mentioned lesions. These factors were variously designated as permeability factor, ${ }^{8)}$ vascular lesion inducing factor, ${ }^{9)}$ transcellular-fluid-forming factor, ${ }^{10)}$ thirst factor ${ }^{11)}$ etc. Confusion and complexity of the problem is due to the

From the Second Department of Internal Medicine, Faculty of Medicine, Kyushu University, Fukuoka 812, Japan.

* Department of Biochemistry, Vanderbilt University, School of Medicine, Nashville, Tennessee 37232, U.S.A.

Received for publication December 9, 1977. 
use of impure substances from the kidney. Understanding of precise nature of the effect of renin on the vascular permeability and lesions is essential for the clarification of this problem. Use of pure renin free from other renal components is prerequisite for such a study and for the identification of the true causative agents of the vascular permeability and damage.

Availability of pure renin preparations in recent years ${ }^{12), 13)}$ prompted the present studies in which the role of renin in the production of tissue edema and vascular lesions were established by using a pure preparation of renin from the submaxillary gland of mouse.

\section{Materials and Methods}

Renin from the submaxillary gland of male mouse was purified to homogeneity by the previously published method. ${ }^{12}$ ) In brief, after extraction in water and precipitation with streptomycin sulfate and ammonium sulfate, it was fractionated by 5 steps of chromatography on columns of Sephadex G-100, diethylaminoethy cellulose, and carboxymethyl cellulose. Each step of purification was performed immediately after the previous step without storage or freezing of the samples. Renin $\mathrm{A}^{\mathbf{1 2})}$ which comprised approximately $85 \%$ of the final pure preparation was used for subsequent experiments. The purity of the preparation was established by electrophoresis on polyacrylamide gel, isoelectric focusing, ion exchange chromatography and ultracentrifugation. ${ }^{12}$ This renin preparation was able to produce $152 \mathrm{ng} \mathrm{cf}$ angiotensin 1 per hour per $\mathrm{ng}$ of enzyme from $4 \mathrm{ml}$ of rat plasma in vitro at $37^{\circ} \mathrm{C}$ and at the optimum $\mathrm{pH}$ of 8 . At pH 7.3 it had greater than $60 \%$ of the maximum activity. ${ }^{13)}$ This preparation (3.2 $\mathrm{mg}$ ) in a $\mathrm{Na}$-acetate buffer was stabilized by the addition of $20 \mathrm{mg}$ of crystalline bovine serum albumin (crystalline grade obtained from Miles-Pentex, Kankakee, Illinois, USA) dialyzed exhaustively against $0.02 \mathrm{M}$ triethylamine-acetate $\mathrm{pH} 6.2$ and lyophilized for storage and transportation. The lyophilized mixture of renin and and bovine serum albumin was dissolved in physiological saline to a concentration of $1.6 \mathrm{mg}$ renin per $\mathrm{ml}$, aliquotized in small volumes and frozen at $-20^{\circ} \mathrm{C}$ untill use. Greater than $90 \%$ of renin activity was recovered after the storage of the dry powder for 1 week at room temperature. Lyophilization of renin without the protection by albumin causes extensive loss in the activity.

Rats used in these experiments were bilaterally nephrectomized under ether anesthesia and catheterized in the left carotid artery for the recording of blood pressure. Five hours later a saddle was mounted on the rat and the catheter was connected to blood pressure recorder through a transducer. Under these conditions arterial blood pressure could be continuously measured in a relatively unrestricted state without anesthesia. After confirming a stable blood pressure recording for more than $60 \mathrm{~min}$, renin solution was injected into the peritoneal cavity.

Solutions used in this experiment contained $0.007,0.07,0.13,0.2,0.35,0.7,2$, $3.5,7,35$, and $200 \mu \mathrm{g}$ of renin per $\mathrm{ml}$ of physiological saline and were injected at a fixed volume of $1 \mathrm{ml}$ per $\mathrm{Kg}$ of body weight.

Blood pressure was recorded for 5 hours in each rat. Eightcen hours after the injection the rat was anesthetized with intraperitoneal injection of sodium amo- 
barbital (100 $\mathrm{mg} / \mathrm{Kg}$, i.p.). After sampling the blood for hematocrit measurement, the rat was sacrificed by exsangunation from the aorta.

Edema in the pancreas was examined macroscopically and the fluid volume of the pleural cavity was measured. The pancreas was fixed with $10 \%$ formalin. Four-micron sections made from paraffin embedded blocks were stained with $\mathrm{HE}$, PAS, and PTAH and examined histologically under a light microscope.

\section{Results}

Table I summarized the elevation of mean arterial pressure, volume of pleural effusion, degree of pancreatic edema, hematocrit value and the severity of vascular lesions in pancreatic arteries of nephrectomized rats 18 hours after the administration of renin solution.

Blood pressure increase was observed in anephric and conscious rats when renin was intraperitoneally administered in quantities greater than

Table I. Pressor Activity, Permeability Actity and Vascular Lesions Observed After the Administration of Renin

\begin{tabular}{|c|c|c|c|c|c|}
\hline $\begin{array}{c}\text { Injection Dose } \\
\text { of Renin } \\
(\mu \mathrm{g} / \mathrm{Kg})\end{array}$ & $\begin{array}{l}\text { BP Elevation } \\
(\mathrm{mmHg})\end{array}$ & $\begin{array}{l}\text { Pleural } \\
\text { Effusion } \\
\quad(\mathrm{ml})\end{array}$ & $\begin{array}{c}\text { Pancreatic } \\
\text { Edema }\end{array}$ & Haemotocrit & $\begin{array}{c}\text { Vascular } \\
\text { Lesions in } \\
\text { Pancreatic } \\
\text { Artery }\end{array}$ \\
\hline 0.007 & $\begin{array}{l}0 \\
0\end{array}$ & $\begin{array}{l}0.2 \\
0\end{array}$ & - & $\begin{array}{l}36 \\
36.5\end{array}$ & $\frac{-}{-}$ \\
\hline 0.07 & $\begin{array}{l}0 \\
0\end{array}$ & 1.0 & - & $\begin{array}{l}36 \\
37\end{array}$ & $\begin{array}{l}- \\
-\end{array}$ \\
\hline 0.13 & 5 & $\begin{array}{l}0 \\
0\end{array}$ & - & $\begin{array}{l}36.5 \\
37\end{array}$ & - \\
\hline 0.2 & 8 & $\begin{array}{l}0 \\
0\end{array}$ & - & $\begin{array}{l}37.5 \\
40\end{array}$ & - \\
\hline 0.35 & 10 & $\begin{array}{l}0.6 \\
1.8\end{array}$ & + & $\begin{array}{l}40 \\
42.5\end{array}$ & H \\
\hline 0.7 & $\begin{array}{l}19 \\
21\end{array}$ & $\begin{array}{l}0.8 \\
1.6\end{array}$ & $+H$ & $\begin{array}{l}43 \\
48\end{array}$ & $\stackrel{+}{\mathrm{H}}$ \\
\hline 2.0 & $\begin{array}{l}36 \\
38\end{array}$ & $\begin{array}{l}1.5 \\
0.5\end{array}$ & $\begin{array}{l}H \\
H\end{array}$ & $\begin{array}{l}47 \\
49\end{array}$ & 卅 \\
\hline 3.5 & $\begin{array}{l}40 \\
45\end{array}$ & $\begin{array}{l}4.8 \\
3.4\end{array}$ & 册 & $\begin{array}{l}56 \\
56\end{array}$ & $\begin{array}{l}\text { W } \\
\text { W }\end{array}$ \\
\hline 7.0 & $\begin{array}{l}48.5 \\
50.0\end{array}$ & $\begin{array}{l}4.8 \\
5.4\end{array}$ & H & $\begin{array}{l}57 \\
64\end{array}$ & 世 \\
\hline 35,0 & 48.5 & $\begin{array}{l}3.0 \\
6.0\end{array}$ & H & $\begin{array}{l}56 \\
62\end{array}$ & 世 \\
\hline 200.0 & $\begin{array}{l}50 \\
50.5\end{array}$ & $\begin{array}{l}3.0 \\
7.0\end{array}$ & 册 & 57 & 世册 \\
\hline$*_{0}, 0$ & $\begin{array}{l}0 \\
0\end{array}$ & $\begin{array}{l}0 \\
0\end{array}$ & 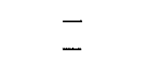 & $\begin{array}{l}35 \\
37\end{array}$ & $\overline{-}$ \\
\hline
\end{tabular}

* control solution containing $170 \mu \mathrm{g}$ BSA in $1 \mathrm{ml}$ physiological saline, which was administered at a rate of $1 \mathrm{ml} / \mathrm{Kg}$ 
$0.13 \mu \mathrm{g} / \mathrm{Kg}$. A steep rise in blood pressure was obtained within first $30 \mathrm{~min}$ (Fig. 1) which was followed by a somewhat less yet persistent elevation of the blood pressure which lasted for more than 5 hours. The dose-response curve is shown in Fig. 2, in which the maximal increase in blood pressure of each rat is plotted against renin dose. The blood pressure elevation reached a plateau when the dose of renin was raised to $7 \mu \mathrm{g} / \mathrm{Kg}$. A dose-dependent sigmoidal increase in blood pressure was observed at doses between 0.07 and $7 \mu \mathrm{g} / \mathrm{Kg}$ as shown in Fig. 2 in which experimentally observed blood pressure elevation is plotted against renin dose along with a best fit dose-response curve
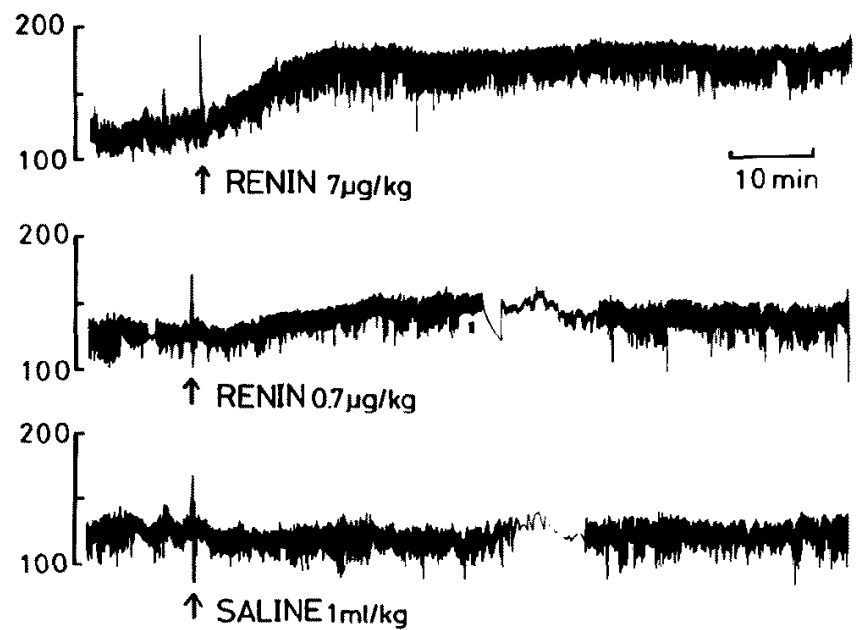

Fig. 1. Blood pressure change induced by renin in unanesthetized, unrestricted, anephric rats.

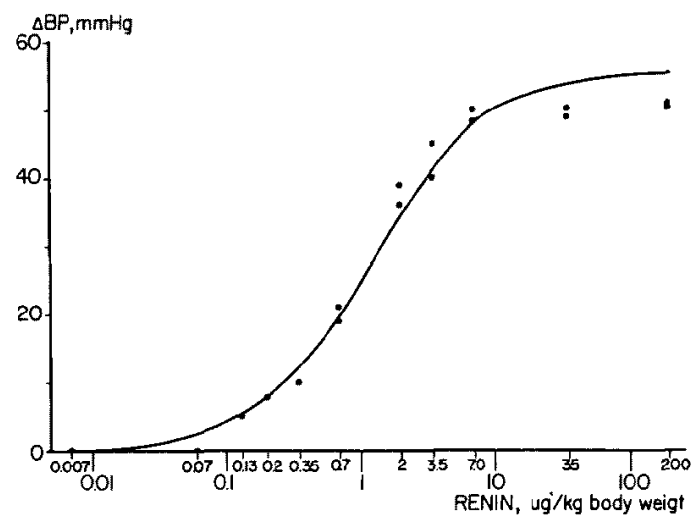

Fig. 2. Dependence of the maximal elevation of blood pressure on the dose of intraperitoneally administered renin. The curve is a best-fit theoretical dose-response curve calculated using the maximal blood pressure elevation of $54 \mathrm{mmHg}$ and the half maximal renin dose of $1.28 \mu \mathrm{g} / \mathrm{Kg}$ of body weight. 
calculated with a half-maximal dose of $1.28 \mu \mathrm{g}$ renin per $\mathrm{Kg}$ body weight and a maximal blood pressure elevation of $54 \mathrm{mmHg}$.

The pleural effusion and the pancreatic edema were more prominent as the amount of renin administered was increased and particularly as the blood pressure elevation became higher than $40 \mathrm{mmHg}$ (Table I). A significant correlation $(r=0.8, p<0.01)$ was observed between the amount of pleural effusion and the degree of pancreatic edema as shown in Fig. 3. The hematocrit values increased sigmoidally in response to the dose of renin between 0.7 and $7 \mu \mathrm{g} / \mathrm{Kg}$ as shown in Fig. 4. Consequently, the hematocrit value also correlated closely with the blood pressure following renin injection ( $r=0.97$, $\mathrm{p}<0.01$ ) as shown in Fig. 5.

In microscopic observations, walls of small arteries and arterioles were eosinophilic and amorphous in $\mathrm{HE}$ staining and were also positively stained with PAS (Fig. 6) and PTAH. Arteries affected were mostly those with dia-

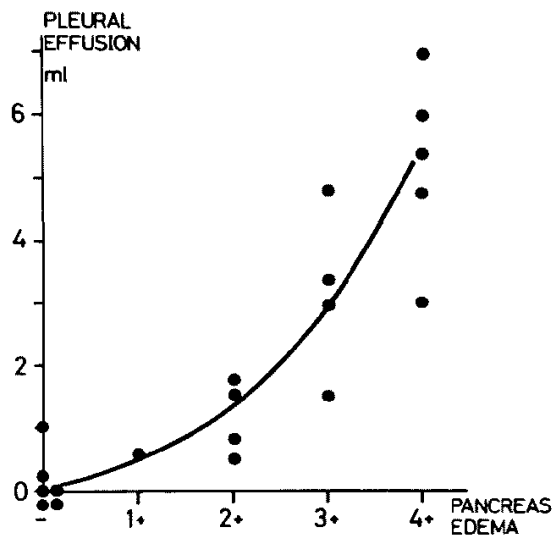

Fig. 3. The relationship between pleural effusion and pancreas edema induced by renin.

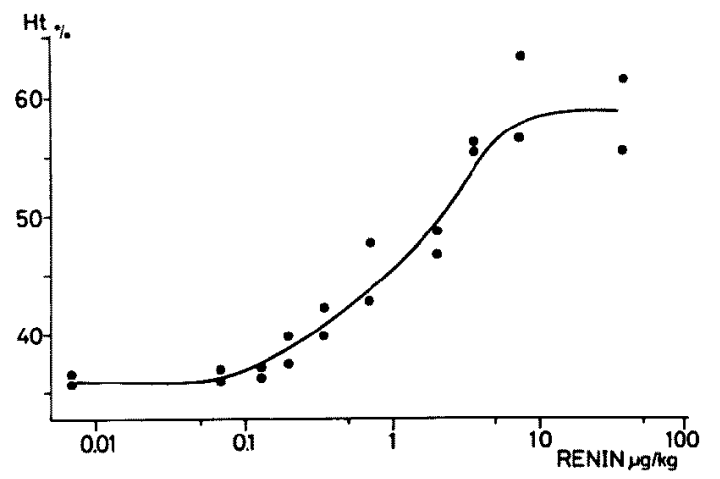

Fig. 4. Dependence of hematocrit value on the dose of renin. 


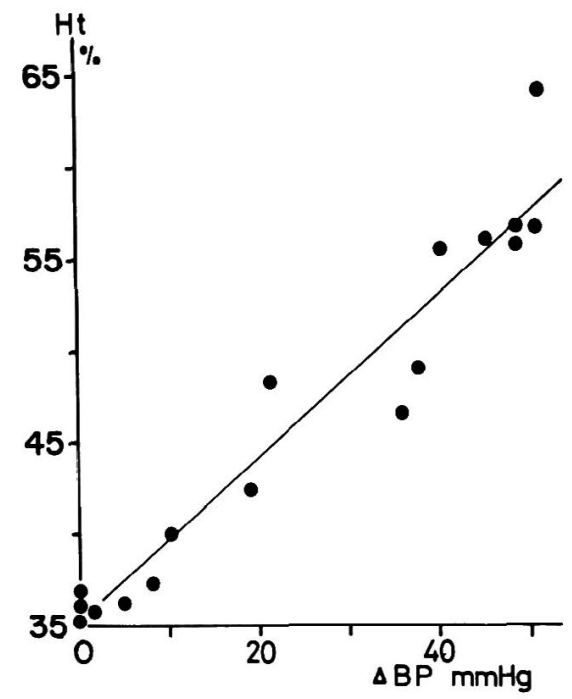

Fig. 5. The relationship between hematocrit value and increase in blood pressure.

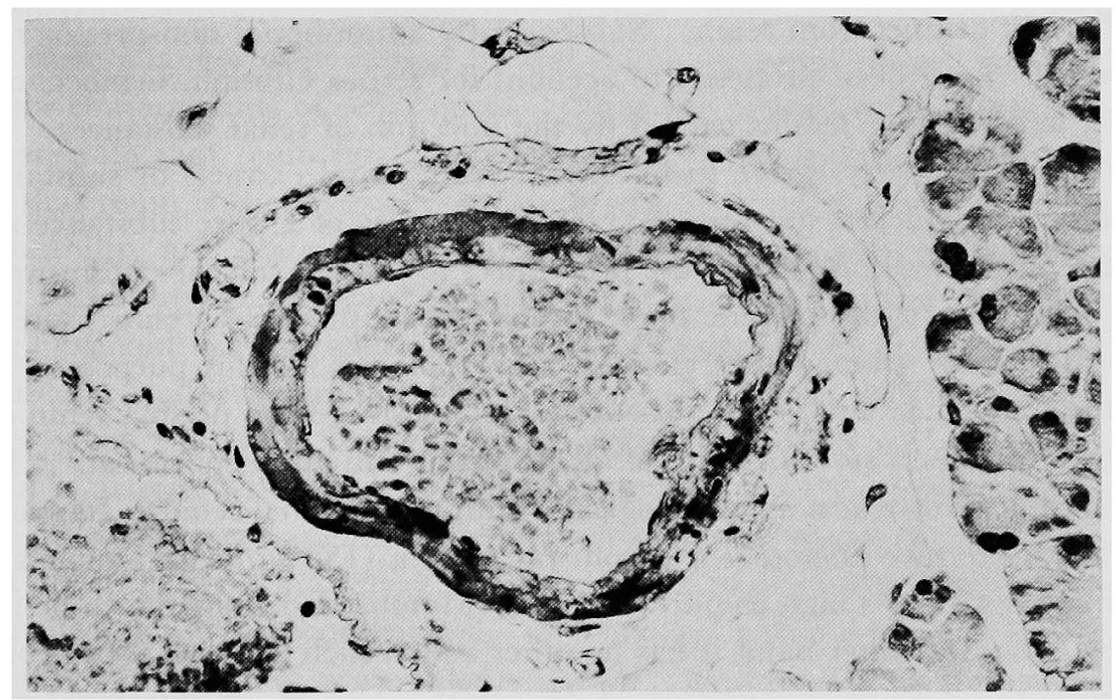

Fig. 6. Fibrinoid necrosis in pancreatic small artery. PAS staining, $\mathrm{X} 470$.

meters ranging between 30 and $200 \mu$. According to our experiences, these findings were similar to those of fibrinoid necrosis found in acute hypertensive vascular lesions observed in experimental renovascular hypertensive rats produced by unilateral renal artery constriction with the intact contralateral kidney. Visual observation of the vascular lesions revealed that the number as well as the extent of the diseased arteries appeared to increase as 
the increasing amount of renin was injected as shown in Table I although the quantitative evaluations of the lesions was difficult. None of the above mentioned effects was observed when only bovine serum albumine was administered, which was used as a carrier and protector of renin (Table I).

\section{Discussion}

We repoted previously that the lysosomal fraction had the highest renin content in the subcellular fractions obtained from remnal cortical extract of normal rats ${ }^{14}$ ) and that the administration of this fraction to anephric rats produced a continuous elevation of blood pressure, pancreatic edema, pleural effusion, and fibrinoid necrosis in pancreatic and mesentric small arteries and arterioles. ${ }^{15}$ ) Based on these observations we suggested that the renin in the kidney cortex is the key factor in the genesis of these lesions. Similar conclusions were obtained by many invastigators using whole kidney homogenates, ${ }^{1}$ ) crude kidney extracts ${ }^{21-51,7)}$ or semi-purified renal renin.6) On the other hand, Asscher and Anson ${ }^{8)}$ suggested the existence of a permeability factor of renal origin distinct from renin. Subsequently a number of non-pressor renal factors $^{9-11}$ ) have been proposed to account for serous effusion, hemoconcentration, and vascular lesions caused by the injection of renal sebstances.

The controversy is due to the use of crude renal extracts or substances, the nature of which is not well characterized. Use of a pure substance such as pure renin should be one of the procedures to provide a clear-cut answer to this problem. In the present study a pure preparation of a renin (isorenin) from the mouse submaxillary gland ${ }^{12)}$ was employed for this purpose. This enzyme, as well as renal renin, liberates angiotensin I from plasma renin substrate and causes a sustained rise of blood pressure in an anephric rat. ${ }^{16)}$ Furthermore, it cross-reacts immunologically with mouse renal renin. Its specific activity to produce angiotensin I from rat plasma (152 $\mathrm{ng} / \mathrm{hr} / \mathrm{ng} \mathrm{renin}$ ) is approximately twice as high as pure rat renin (Matoba and Inagami, to be published). On the other hand it has no other action such as general proteolytic activity (unpublished observation of Inagami). Use of an extrarenal renin provides additional advantage since it serves to eliminate completely the possibility of contamination with renal non-pressor substances which have been postulated as the factor(s) causing the vascular lesion. Furthermore the purity of the submaxillary gland renin used in this study has been ascertained by a number of physical and chemical criteria.

The renal renin of the highest purity so far employed for the study of its effect on vascular permeability was the 300-fold purified preparation used by Cuth bert and Peart. ${ }^{6}$ This renal renin administered at a dose of 
$2 \mathrm{mg} / 100 \mathrm{Gm}$ body weight resulted in an elevation of blood pressure of approximately $60 \mathrm{mmHg}$. In the present study, in which submaxillary gland renin administered at a dose of $0.7 \mu \mathrm{g} / 100 \mathrm{Gm}$ body weight in an almost identical manner as that of Guthbert and Peart $\left.{ }^{6}\right)$ gave a blood pressure elevation of $50 \mathrm{mmHg}$. Assuming comparable levels of intrinsic activity of these renins, the submaxillary renin preparation employed in this study would be 2,800 times purer than the renal renin used in the previous study above mentioned. In fact, since pure renin can be prepared from rat kidney by greater than 3,000-fold purification (unpublished observation by Matoba and Inagami) the 300 -fold purified renal renin used by Cuthbert and Peart seems to be only $10 \%$ pure.

Thus, since it could contain a large amount of the renal components, the use of such impure preparation did not allow unequivocal conclusion as to whether renin was the true and the exclusive causative agent for the vascular permeation and lesions.

This study has clearly demonstrated parallelism between the blood pressure elevation on one hand, and pleural effusion, pancreatic edema, hematocrit increase, and vascular lesions on the other. Furthermore, it must be noted that these changes were caused by the action of renin alone, not by nonpressor contaminants of renal origin. Thus the present results unequivocally demonstrate that renin has both pressor and vascular permeability activities and that renin is the necessary and sufficient causative agent for the vascular permeability and lesion. Thus conclusion is in agreement with that postulated by Cuthbert and Peart ${ }^{6}$ ) by using only partially purified renal renin.

Fibrinoid necrosis which seemed to be caused by increased permeability of vascular wall was found predominantly in the arteries of 30 to $200 \mu$ in diameter when examined by light microscopy. Very little abnormalities were found in arteries with diameters larger or smaller than this range even in animals bearing a large amount of pleural effusion and severe pancreatic edema. This susceptibility could reflect elevated sensitivity of arteries of this dimension to renin-induced vasoconstriction. Mechanism underlying such differential vasculotoxic action of renin is not known. Systematic studies seem to be needed to clarify the mechanism leading to vascular damage in malignant hypertension.

\section{AGKNowledgements}

This study was partly supported by the Ministry of Education of Japan through a research grant No. 911911 and by National Institutes of Health of USA through research grant HL-14192. 


\section{REFERENCES}

1. Winternitz MC, Mylon E, Waters LL, Katzenstein R: Studies on relation of kidney to cardiovascular disease. Yale J Biol Med 12: 623, 1939-40

2. Masson GMC, Kashii C, Panisset J, Yagi S, Page I: Production of hypertension and vascular disease by kidney extracts. Cirulat Res 14: 150, 1964.

3. Nairn RG, Masson GMC, Corcoran AC: The production of serous effusions in nephrectomised animals by the administration of renal extracts and renin. J Path Bact 71 : 155, 1956

4. Giese J: Pathogenesis of vascular disease caused by acute renal ischaemia. Acta Path Microbiol Scandinav 59: 417, 1963

5. Cuthbert MF, Asscher AW, Jones JH: Characterization of a vascular permeability factor of renal origin. Clin Sci 31: 325, 1966

6. Cuthbert MF, Peart WS: Studies on the identity of a vascular permeability factor of renal origin. Clin Sci 38: 309, 1970

7. Onoyama K, Oniki H, Eto T, Tanaka K, Omae T: The kidney factors in the production of acute hypertensive vascular lesions. Jap Circulat J 38: 1111, 1974

8. Asscher AW, Anson SG: A vascular permeability factor of renal origin. Nature 198: 1097, 1963

9. Nakao K, Ikeda M, Fujii J, Terasawa F, Kurihara H, Kimata S, Matsushita S, Yamaguchi H: Acute vascular lesions produced by selected nonpressor renal cortical extracts. Jap Circulat J 30: 539, 1966

10. Namba S, Hiramatsu Y, Kusunoki F, Okuda K, Sokabe H: Partial purification of a transcellular-fluid-forming factor from the renal cortex. Jap Circulat J 32: 1585, 1968

11. Kira J, Ogino K, Takayasu M: Haemoconcentrating substance and vascular permeability factor from rat kidney lysosomes. Jap Circulat J 32: 1, 1968

12. Cohen S, Taylor J, Murakami K, Michelakis AM, Inagami T: Isolation and characterization of renin-like enzymes from mouse submaxillary glands. Biochemistry 11: 4386, 1972

13. Murakami K, Inagami T: Isolation of pure and stable renin from hog kidney. Biochem Biophys Res Communs 62: 757, 1975

14. Onoyama K, Hara M, Tanaka K, Omae T: Renin content in subcellular fractions of normal rat Kidney extract. Jap Heart J 14: 440, 1973

15. Onoyama K, Hattori $N$, Omae $T$, Katsuki S: Vascular lesions produced in bilaterally nephrectomized rats by injection of fractionated renal coritical extracts. J Jap Coll Angiol 11: 163,1971

16. Michelakis AM, Yoshida H, Menzie J, Murakami K, Inagami T: A radio immunoassay for the direct measurement of renin in mice and its application to submaxillary gland and kidney studies. Endocrinology 94: 1101, 1974 